OPEN ACCESS

Edited by:

Joni Jupesta,

SMART Research Institute

(SMARTRI), Indonesia

Reviewed by:

Jennie C. Stephens,

Northeastern University, United States

Matthijs Bogaards,

Central European University, Hungary

Felix Butzlaff,

Vienna University of Economics and

Business, Austria

Piergiuseppe Fortunato,

United Nations Conference on Trade and Development (UNCTAD),

Switzerland

*Correspondence: Ethemcan Turhan e.turhan@rug.nı

Specialty section: This article was submitted to Sustainable Energy Systems and

Policies,

a section of the journal Frontiers in Energy Research

Received: 23 September 2019 Accepted: 29 September 2020 Published: 28 October 2020

Citation:

Sorman AH, Turhan E and RosasCasals M (2020) Democratizing Energy, Energizing Democracy: Central Dimensions Surfacing in the Debate.

Front. Energy Res. 8:499888. doi: 10.3389/fenrg.2020.499888

\section{Democratizing Energy, Energizing Democracy: Central Dimensions Surfacing in the Debate}

\author{
Alevgül H. Sorman ${ }^{1,2}$, Ethemcan Turhan ${ }^{3,4 \star}$ and Marti Rosas-Casals ${ }^{5}$ \\ ${ }^{1}$ Basque Centre for Climate Change (BC3), Leioa, Spain, ${ }^{2}$ IKERBASQUE, Basque Foundation for Science, Bilbao, Spain, \\ ${ }^{3}$ Faculty of Spatial Sciences, University of Groningen, Groningen, The Netherlands, ${ }^{4}$ Environmental Humanities Laboratory, \\ Division of History of Science, Technology and Environment, Royal Institute of Technology (KTH), Stockholm, Sweden, \\ ${ }^{5}$ Universitat Politecnica de Catalunya (BarcelonaTech-UPC), Barcelona, Spain
}

This perspective piece sets out to contribute to the academic and practitioner debates around energy transitions and democracy initiatives in the age of a climate crisis. For tackling present-day energy challenges in a democratic, equitable and just manner, critical social science and humanities research on meaning and materialities, new actors and narratives, values and democracy is indispensable. In doing so, we centralize our work around three fundamental axes: The Concept, reflecting on the energy itself and revitalizing its essence; The Political, embracing the value laden, political and gendered nature of energy, and recognizing citizens' initiatives as counter currents to centralized energy decision-making; and The People, anticipating the far right's posttruth narratives that jeopardize planetary futures. We contend that "normative, political and embodied" research and praxis can serve for diversifying the energy transition debate as well as energizing bottom-up community led initiatives in order to democratize the energy playing field of recent times.

Keywords: energy democracy, climate crisis, equity, sustainability, energy justice, decarbonization

\section{INTRODUCTION}

There has been growing research and practice, notably in the last two decades, attempting to tackle energy transition discussions in a more democratic, equitable, just and sustainable manner. Negative socio-ecological impacts of fossil based economies have been mirrored though extractive modes of production leading to environmental conflicts (Martinez-Alier, 2009; Scheidel, et al., 2020), unequal ecological exchange (Hornborg, 2011) and corporate profits of multinationals that have been perpetuating inequalities and exacerbating disparate vulnerabilities around communities around the world (Stephens, 2019). As a response, energy democracy has emerged as a politically loaded response referring to a process, an outcome or a goal depending on the context it is used (Szulecki and Overland, 2020). Not only does it emphasize a collective demand to democratize production, transmission and consumption of energy; energy democracy at its core also calls for the need to redistribute political power via resisting, restructuring and/or reclaiming energy systems (Sweeney, 2012; Burke and Stephens, 2018; Szulecki, 2018; Van Veelen and Van der Horst, 2018; Stephens, 2019).

Alternative currents to mainstream energy research, have recently also been enriched with the infiltration of a healthy dose of social sciences and humanities perspectives with attention given to the normative dimensions of energy challenges. The study of energy systems, which previously was 


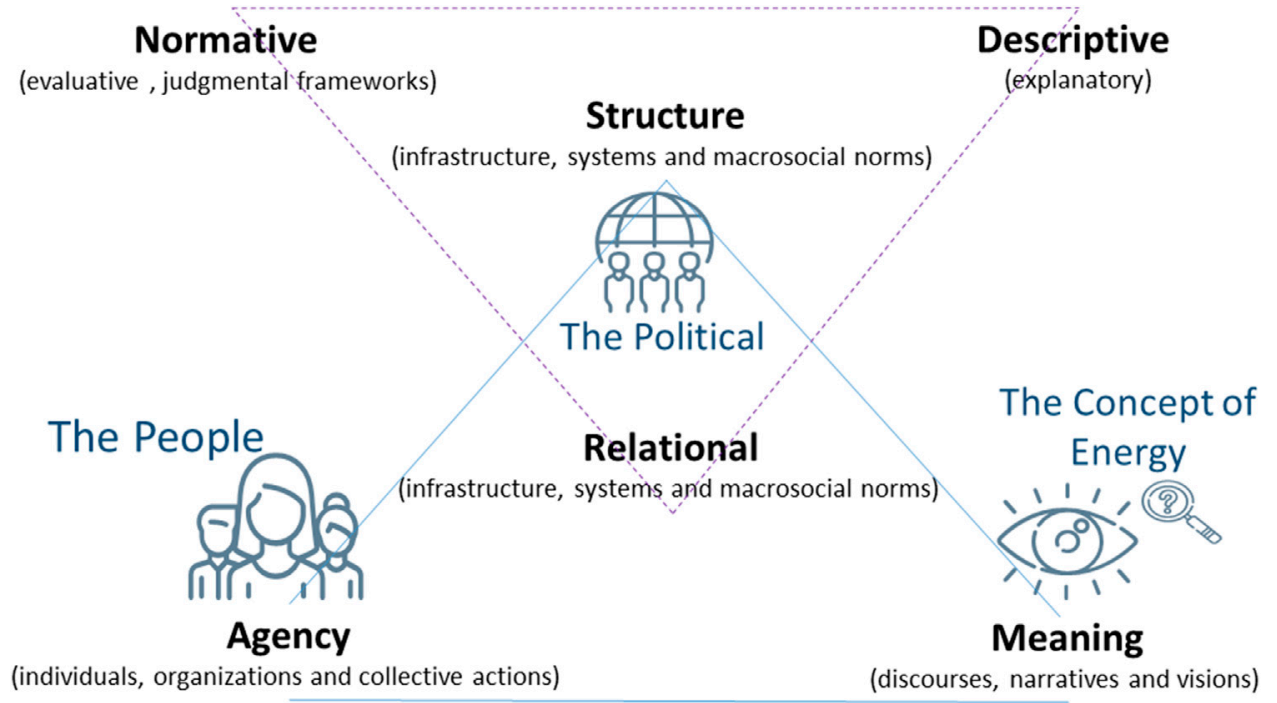

FIGURE 1 | Agency, structure, meaning; relations, normativity and descriptivity in social theories. Adapted from Sovacool and Hess (2017) under the Creative Commons Attribution-NonCommercial 4.0 License.

dominated by engineering or economics disciplines or, at the very best, by mainstream geopolitics of access, is now a thriving field of critical social science research with ever-expanding work on new actors, materialities, values, worldviews, democracy, and justice (Castree, 2014; Sovacool, 2014; Sovacool et al., 2018; Jenkins, 2020). Simultaneously, and confronting the "liquidity" of the modern society, marked by global capitalist economies with their increasing privatization of services (Bauman, 2000), we also observe rising scholarly interest and effort in self-sufficiency, energy sovereignty and planned reduction of total energy throughput in contrast to central forms of governance and provision mechanisms (Kunze and Becker, 2015; Becker and Naumann, 2017; Alexander and Yacoumis, 2018). We see the praxis of these new approaches brought to life by new societal actors materializing in initiatives such as re-municipalization, renationalization and citizens' collective control of energy production and/or distribution. We argue that such research and application is not only central to the energy transition and democracy debate in itself, but is also key in redeeming socio-political dynamics, recently over flooded with post truth political narratives, deteriorating democracies.

In this perspective piece, our aim is to unpack some of the dimensions that we believe are important in discussing energy transitions along the broad spectrum of the concept, the political and the people. We revisit some critical discussions as how we relate to energy, how energy injustices are an end game of political decisions especially in an era of post truth politics and how ultimately the people, are central agents in organizing and leading this transition which not only focuses on green alternatives but on one that also reduces vulnerabilities and inequalities. We believe that several of the dimensions we highlight in this perspective piece fill in some of the research voids in recent literature while representing only some of numerous vital dimensions that need energizing. We have brought these together under the trias of
Concept-Politics-People which enable discussions across agency, structure and meaning brought together across descriptive, normative and relational factors (for more details see Figure 1).

Our title emphasizes two synergies: first, democratizing energy: highlighting the importance of plurality of disciplines, voices and approaches in energy transitions and democracy principles and praxis; and the latter: energizing democracy; using energy as a means to an end, opening up authoritarian agendas and politically manoeuvred spaces to one that is closer to and governed by the people. Albeit bringing together energy and democracy may provide a "fluid" and "pluralistic" field of research (Szulecki and Overland, 2020), we see this in itself as the added value of energy democracy debate.

\section{UNPACKING THE CRITICAL AXES IN ENERGY RESEARCH}

\section{The Concept: Energy}

Revisiting the concept of energy allows us to elaborate on its meaning and related aspects which, at times, may go unrecognized and unacknowledged via other analytical approaches (Miller et al., 2013). First and foremost, similar to other scholar's calls, we claim that we need a redefinition of the concept of energy and a different understanding of how societies relate to and co-evolve with energy in an age of "the great derangement" (Nightingale et al., 2020). Conceptually and somewhat conservatively, most scholarly work to date has envisioned energy as something that "flows in" and "flows out", interpreting it as a "thing" or a mere "resource" (Huber, 2009)-rather passive stuff that is spiritless (Nelson 2003), essentially raw, brute and dull despite being foundational to life. Instead, the flourishing fields of social science and energy humanities indicate that we need to transcend into a redefinition 
of energy as a live source, replacing its conceptualization as a prime mover of vitality (Bennett, 2010) thereby giving it a new meaning in terms of its materiality and understanding energy as a social relation interwoven through the material, calorific, geological or topographic aspects (Hoffmann, 2018). This vision is encountered, for example across Māori communities, the Indigenous peoples of New Zealand, where energy is conceptualized in a holistic manner, resembling "a series of relationships in entire ways of life." (MacArthur and Matthewman, 2018).

Contributions from energy humanities scholarship has, in recent years, established a promising line of research that socially and culturally explores the different ways we interact with energy, wondering the essential need for it (Szeman and Boyer, 2017). Energy researchers therefore have begun to scrutinize transformational behavioral change, to inspire collective action bound by ecological principles (Amel et al., 2017) and investigate instrumental, moral, shared and nonmaterial values to look into intrinsic relations of human/nonhuman connections (Chan et al., 2018). Furthermore, novel methods rooted in psycho-social methodologies, revealing how people engage with and to energy and climate change, are also emerging (see Hoggett, 2019). Among other topics, there has also been special attention toward empathetic work, listening, collaborative conversations, art, expression and connectivity to nature (Galafassi et al., 2018). Research has also embraced new narratives: those that encourage more intelligent and sustainable engagements with "vibrant matter" that sustains our complexsocieties (Tainter, 2011), and those that are ever-so ambitious, to avoid a global carbon lock-in with catastrophic consequences for the most vulnerable of the planet.

The problem is that mainstream energy research often takes the societal "need" for energy for granted and overlooks the fact that energy systems are socially and politically constructed (Shove and Walker, 2014). Particularly, the social scientific study of energy has enabled us to delve deeper into questions of how energy infrastructures are imagined, why they are designed the way they are and how they operate at multiple temporal and spatial scales. Meanwhile such inquiries also inspire further ones such as: who is benefitting from these vital energy flows; and how an object-focused inquiry into assemblages, political economy, and socio-technical shifts can improve our understanding of this "productively chaotic" field (Bridge et al., 2018b; Balmaceda et al., 2019).

\section{Manoeuvring Between Descriptive, Relational, and Normative Tasks}

As Van Veelen et al. (2019: 2) suggest, "energy without any social, political, or economic contextual framing, its production and use, historical trajectory, path dependencies, lock-ins, and spatial extent is reduced to its technological aspects: flowing electrons, and engineering and resource challenges." Critical social science approaches to energy systems, instead, base the analysis across agency, structure, meaning, relations, norms and descriptive tasks (see Figure 1 based on Sovacool and Hess, 2017). While the first three dimensions are linked with the more traditional (descriptive) disciplines of social sciences, relations and norms are rather guided by ethics and social justice. Descriptive claims, however, can also draw attention to moral choices like meaningmaking in the hybridity of human/non-human systems as well as our relational values with energy and our interactions encompassing further normative dimensions (Jenkins et al., 2018). In this piece, we bring together the different meanings of how we believe agency, structure and meaning are played out across the three dimensions: the people, the political and the concept of energy itself.

Transition vs. Transformation: Is This the Question? Similar to the debates that revolve around incremental transition vs. radical transformation in sustainability challenges (Scoones, 2016), analogous discussions emerge regarding pathways for energy transitions. While a narrow definition of resource switching or a wishful technological leapfrogging is often embraced, critical literature indicates that a comprehensive transformation of energy landscape requires new sociopolitical power relations to counter socio-technical incumbencies avoiding deep decarbonization (Stirling, 2019). This approach is well grounded in action-oriented, transformational climate change science (Fazey et al., 2018).

The evolution of the energy debate, from one being dominated by economic and policy analyses and engineering responses to a wider focus on agency, power and stratification has also triggered multiple contested framings of societal energy challenges (Van Veelen et al., 2019). Despite wishful thinking on the efficacy of transitions, the 2019 Emissions Gap Report (UNEP, 2019) indicates that the world is heading for a $3.2^{\circ} \mathrm{C}$ temperature rise by the end of the century with G20 nations accounting for $78 \%$ of all emissions. Nationally Determined Contributions under the Paris Agreement fail in terms of ambition, where a threefold reduction of emissions is needed to stabilize the atmospheric system to well-below $2^{\circ} \mathrm{C}$ and more than fivefold to achieve the $1.5^{\circ} \mathrm{C}$ target (ibid.). The abrupt decline of emissions driven by Covid-19 pandemic response provides a novel opportunity to rethink the desirability of current energy system and suggest alternatives, although this momentum is unlikely to be sustained in the absence of coordinated downscaling efforts. In this context, the energy transition vs. all-out transformation debate has recently shifted toward the Green New Deal, which seeks to distance itself from mainstream "green economy" arguments. This, Green (er) New Deal emerges as a promising pathway insofar as it diverges away from profit-hungry oligopolies and techno-fixes such as carbon capture or solar engineering. However, unless implemented with a critical vision toward reducing overall metabolism of societies, a global Green New Deal may also risk reproducing the accelerationist business as usual via renewables. Renewable energy alone does not necessarily imply democratic, equal and just access and use since societies could, hypothetically, move to a $100 \%$ renewable energy world, that is entirely under corporate control, led by a handful of large and powerful global renewable energy companies (Stephens, 2019). Same goes for local energy, which can be a tool of exclusion under isolationist, xenophobic political contexts. This is where democratizing energy plays a crucial role, in which people have agency as 
prosumers and hold direct stakes in the decision making of how their energy is generated. In sum, a transformation implying radically changed metabolic dependencies and ultimately challenging the economic growth paradigm itself requires highly ambitious structural, political and social changes that confront the status quo.

\section{Space, Direction, and Time}

Spatial, directional and temporal dimensions of the energy debate are much better catered for by critical research today than the recent past. We believe that this is useful, promising and necessary for the following purposes:

- Space: In a carbon-constrained world with scarcities (Bridge, 2015) where limits are both real and relational (Kallis, 2019), research on energy geographies serves as an anchor in exploring new energy frontiers for a radically different, sustainable societal re-organization (Baka and Vaishnava, 2020). A switch from the dense, low entropic and geospatially specific fossil fuel-led energy system to a renewable dominant, high entropic, mixed energy provision system, creates new spaces and dynamics in territorial terms (Schiedel and Sorman, 2012) as much as it fuels contestation (Huber and McCarthy, 2017). New frontiers of renewable energy expansion require as much attention as regards the environmental conflicts they produce as fossil fuel production, consumption and distribution systems (Scheidel et al., 2020).

- Direction: Exploring the directionality of new forms of energy provision is also very important. Questions concerning the place of origin and final destination of new energy provision systems, on which and whose terms, need to be posed. We must inquire whether the rush to renewables create new spatial fixes and neo-colonial relations by favoring flows from the global South to the global North, from the rural to the urban or between pockets of plenty and none within those broad clusters (McCarthy, 2015).

- Time: The speed at which a transition can take place is one of the crucial elements in the transition debate (Sovacool, 2016). Despite global temporal horizons such as Sustainable Development Goals (SDGs) set at 2030 and net carbon neutrality debates picking 2050 as their target, there still seems to be a lack of faith in intergovernmental processes for having failed in the past 3 decades to meet absolute decarbonization objectives. This, we argue, will increasingly be the case in a world ridden with authoritarian populism and nationalist isolationism while facing multiple unknown unknowns that humanity may experience including the on-going and post Covid-19 pandemic itself.

Therefore, we urgently need to create platforms for popular deliberative discussions over where, how and when the objectives that we set out for energy transition are likely to be achieved, and what it is that is ultimately desirable.

\section{The Political: Re-Claiming the Energy Sphere}

We claim that confronting the climate crisis beyond slogans requires us to go beyond technical fixes, navigate between descriptive and normative tasks, while also confronting energy injustices with contested politics (Nightingale et al., 2020). Ideally, this implies widening the energy debate about the desirability of multiple pathways through which we imagine more equitable, democratic and sustainable futures. Social, cultural, political, material and immaterial dimensions of energy call for attention to multiple "languages of valuation" (Martinez-Alier, 2009) and value pluralisms in and beyond the energy realm. This value-laden, complex and contested nature of the energy debate makes it an ideal field for putting democratic politics at the center of attention (Burke and Stephens, 2018). Further attention to energy democracy with its deliberative characteristics is perhaps most needed to understand potentials for transition and/or transformation under nondemocratic conditions (Delina, 2018).

\section{Energy Security vs. Energy Sovereignty}

Energy security, which dominated global debates for a fairly long time, dictates certain transition narratives with priority placed on the uninterrupted availability of energy sources at an affordable price. However, questions of where the energy comes from and who is in control have long been avoided in these discussions over securitization (Cherp and Jewell, 2011). From renegotiating oil extraction contracts as service provisioning in Ecuador to expanding the extractivist logic as rent sharing in the case of Chinese built dams overseas, securitized narratives of national interest side-line the debates on who controls, regulates and manages energy. ${ }^{\text {a }}$ Energy sovereignty contrasts such a framing of energy security by acknowledging uneven power dynamics, values and identities attached to production and consumption.

\section{Bottom-Up Energy Action}

The role of community, citizens and local authorities in these democratic energy transitions have been well documented in terms of their transformative potential and nature (Burke, 2018). Advancements in politicizing and understanding community's roles in the energy debate show that framing responses to energy challenges as a co-evolution of human and more-than-human systems allow for much more rapid transition than top-down cumbersome structures (Islar and Busch, 2016). Opening up of a whole new research field with a clear focus on relationalities and making energy as a public interest is an important step toward that direction (Chilvers and Pallett, 2018). Such initiatives have helped overcome two main hurdles: initially to convince people that climate change is real and important and second to move from acceptance to action while strengthening the idea that community-led action can indeed lead the way. In Europe alone, REScoop (the European federation of citizen energy cooperatives) have over 1,500 European energy cooperatives

${ }^{\text {a}}$ For a global map of environmental (in)justices with over 3,000 cases, see https:// ejatlas.org/. 
registered within their network. Moreover, a recent report on the re-municipalization of energy services showed that there were over 370 cases from across the world by the end of 2019 (Kishimoto et al., 2020). This type of community action not only results in a more democratic control, but also increases the quality of services and provide better working conditions to serve the interests of the people and the planet.

\section{The Gendered Nature of Energy Transitions}

Although women play a vital role in shaping and driving energy transitions (see, for instance, Allen et al., 2019), this is still far from being the norm. The contemporary energy predicament undervalues and underestimates women's visions and solutions (Lieu et al., 2020). This landscape often renders women as the most vulnerable group feeling the brunt of unjust energy systems and decisions, with hardly any say on or representation in the directionality of change. Therefore, it is imperative to shed a gender-conscious light on the study of energy-society relations (Ryan, 2014). Gender mainstreaming in energy decision-making and action, both in terms of numbers (representation) and meaningful participation (incorporated voices) need to guide transitions (Winther et al., 2020).

\section{The People: Against Post-truth Energy Politics}

Last but not least, the deterioration of democratic processes and the rise of populism over the past decade across the world has given rise to post-truth politics (D'Ancona, 2017). Historically connected with epistemic debates about postmodernity and relativism, posttruth politics today are the lifeline of typical right-wing, populist parties and extremist denialism narratives, and encourage a particular way of doing politics, based on a radically opposite form to scientific methods and inquiry (Stanley, 2018). The late modernity trait of ever-increasing processes of privatization of previously collective affairs and services in the global capitalist economies (Bauman, 2000), makes the particular case of energy transitions debates a fruitful arena for ambivalent and ambiguous narratives (and obviously narrators). The rise of uncertainty and discontent, radically undermining individual aims for collective goals (Bauman 2001) has resulted in collective action becoming increasingly difficult. While the "positional nature of sustainable energy transformation" and value plurality are long-standing topics, how post-truth politics enable and reinforce political polarization in shutting down democratic claims to energy access, control and ownership are still understudied (Fraune and Knodt, 2018). Such distortion of the epistemic field is as much preferred by political interests as they are by private, economic interests (Ruiz Cayuela and Turhan, 2019). Understanding how post-truth politics, as is championed by extremists, affect the role of energy in the context of global democracy requires scrutiny, one which calls for solid, situated knowledge production. Critical social science on energy, working across scales can serve to fight back post-truth politics by showing how distorted bits of knowledge serve to preserve existing structures of social power (Bridge et al., 2018b). We contend that "normative, political and embodied" research strategies (Nightingale et al., 2020) are fundamental to achieve the democratization of energy and defeat the extremists particularly mischievous approach to planetary futures either through denialism or eco-fascism. This requires nothing short of transforming the research practice itself and re-designing it toward "providing adequate food, water, energy, income, education, resilience, voice, jobs, health, and gender and social equity for all, in an ecologically safe operating space for humanity" (Shrivastava et al., 2020: 338).

In practice, the principles of resisting, reclaiming and restructuring have been set as intentional guidelines for confronting post truth politics in action. The most visible resistance, for example has been reflected in the attempts to blocking vs. restoring the Keystone XL pipeline project; which is not only dividing high-level politics in the US but is also urging Canada to reconsider its energy politics in action (Mabee, 2020). Along a similar vein, pressure from advocacy groups has led to half of the public universities in the United Kingdom to divest or pledge to divest from fossil fuels (Taylor, 2020). Reclaiming ownership is also finally playing out, were positive energy districts are emerging in urban centers (JPI Urban Europe/SET Plan Action 3.2, 2020). Several regulatory barriers are also being lifted where in for example in Spain in 2019, the Solar Energy Tax was finally scrapped and a new regulation giving rights to self-production and communal production/management is finally paving way for new models of communal rooftop energy provision in urban communities (BOE, 2019). Restructuring, both in terms of infrastructure and systems, is also slowly making way in the face of the climate emergency. Even though there is still a major restructuring required, BP, a core representative of the fossil lobby, has also recently announced that it is going to shift away from fossil fuels and toward low carbon energy within the next decade (Ambrose, 2020).

\section{CONCLUSIONS}

In this perspective piece, we offer a pluralist viewpoint from an array of literature such as: climate psychology to energy geographies, to environmental and energy justice as different disciplines which shed light to the contemporary energy debate. We also bring forth several insights from bottom-up initiatives that are rolling forward at tremendous speed, in reclaiming power to the people for democratizing energy projects.

By embracing critical yet care-full scientific principles, our intention has been to unpack several of the dimensions that we believe are important in theory and in operationalization. As the argument goes, we applaud the achievements of bottom-up energy democracy pioneers which energize democratic achievements, while we also highlight the dangers of posttruth energy politics obscuring the agenda with isolationist eco-fascist or techno-utopian fallacies. We highlight the necessity of transcending false promises and not-ambitiousenough-ambitions for a real transformative energy agenda to take off, both in terms of research and action.

A truly transformational energy research needs to go beyond the technical and descriptive while taking on-board critical social science research focusing on agency, structure, meaning while scrutinizing plural understandings and the relations mostly 
pertaining to the normative. We believe that our role as critical researchers is to nurture this deliberative dialogue with special attention given to differences on how energy transitions may unfold and for whom. Likewise, we feature the importance of discussing power embedded within space, direction and time; gendered dynamics ingrained in voices that are heard that inevitably define core energy decisions and research agendas. This ultimately, urges and prompts those seeking to produce socially relevant energy research to tackle some hard questions on what it means to democratize energy in a period of lockdowns and climate strikes as well as what it means to re-energize the paling democracies around the world today.

\section{REFERENCES}

Alexander, S., and Yacoumis, P. (2018). Degrowth, energy descent, and 'low-tech' living: potential pathways for increased resilience in times of crisis. J. Clean. Prod., 197, 1840-1848. doi:10.1016/j.jclepro.2016.09.100.

Allen, E., Lyons, H., and Stephens, J. C. (2019). Women's leadership in renewable transformation, energy justice and energy democracy: redistributing power. Energy Res. Social Sci. 57, 101233. doi:10.1016/j.erss.2019.101233.

Ambrose, J. (2020). BP enjoys share bounce after unveiling plans to shift away from fossil fuels. The Guardian, 4 Aug 202017.45 BST, https://www.theguardian. com/business/2020/aug/04/bp-dividend-covid-record-loss-energy-oil-gas

Amel, E., Manning, C., Scott, B., and Koger, S. (2017). Beyond the roots of human inaction: fostering collective effort toward ecosystem conservation. Science 356 (6335), 275-279. doi:10.1126/science.aal1931.

Baka, J., and Vaishnava, S. (2020). The evolving borderland of energy geographies. . Geography Compass. e12493.

Balmaceda, M., Högselius, P., Johnson, C., Pleines, H., Rogers, D., and Tynkkynen, V.-P. (2019). Energy materiality: a conceptual review of multi-disciplinary approaches. Energy Res. Social Sci. 56, 101220. doi:10. 1016/j.erss.2019.101220.

Bauman, Z. (2000). Liquid modernity. Cambridge: Polity Press.

Bauman, Z. (2001). The individualized society. Cambridge: Polity Press.

Becker, S., and Naumann, M. (2017). Energy democracy: mapping the debate on energy alternatives. Geogr. Compass. 11 (8), e12321. doi:10.1111/gec3.12321.

Bennett, J. (2010). Vibrant matter: a political ecology of things. Durham, NC: Duke University Press.

BOE (2019). Royal Decree 244/2019 of April 5 (BOE 05.04.2019). Núm 83, 35674-35719. in Spanish) https://www.boe.es/boe_catalan/dias/2019/04/06/ pdfs/BOE-A-2019-5089-C.pdf

Bridge, G., Barca, S., Özkaynak, B., Turhan, E., and Wyeth, R. (2018b). Towards a political ecology of EU energy policy. Advancing energy policy. Cham: Palgrave Pivot. 163-175.

Bridge, G. (2015). Energy (in)security: world-making in an age of scarcity. Geogr. J. 181 (4), 328-339. doi:10.1111/geoj.12114.

Bridge, G., Özkaynak, B., and Turhan, E. (2018a). Energy infrastructure and the fate of the nation: introduction to special issue. Energy Res. Social Sci. 41, 1-11. doi:10.1016/j.erss.2018.04.029.

Burke, M. J. (2018). Shared yet contested: energy democracy counter-narratives.. Front. Commun. 3, 22. doi:10.3389/fcomm.2018.00022

Burke, M. J., and Stephens, J. C. (2018). Political power and renewable energy futures: a critical review. Energy Res. Social Sci. 35, 78-93. doi:10.1016/j.erss. 2017.10.018.

Castree, N.. Energy: humanities frame the aims (2014). Nature 513, 33. doi:10. $1038 / 513033 \mathrm{c}$.

Chan, K. M., Gould, R. K., and Pascual, U. (2018). Editorial overview: relational values: what are they, and what's the fuss about? Curr. Opin. Environ. Sustain. 35, A1-A7. doi:10.1016/j.cosust.2018.11.003.

Cherp, A., and Jewell, J. (2011). The three perspectives on energy security: intellectual history, disciplinary roots and the potential for integration. Curr. Opin. Environ. Sustain., 3 (4), 202-212. doi:10.1016/j.cosust.2011.07.001.

\section{AUTHOR CONTRIBUTIONS}

All authors have contributed equally to this paper.

\section{ACKNOWLEDGMENTS}

Alevgul $\mathrm{H}$. Sorman would like to acknowledge the PARIS REINFORCE project from the European Union's Horizon 2020 research and innovation programme under grant agreement No 820846 and the María de Maeztu excellence accreditation MDM-2017-0714 of BC3.

Chilvers, J., and Pallett, H. (2018). Energy democracies and publics in the making: a relational agenda for research and practice. Front. Commun. 3, 14. doi:10.3389/ fcomm.2018.00014.

Delina, L. L. (2018). Can energy democracy thrive in a non-democracy? Front. Environ. Sci. 6, 5. doi:10.3389/fenvs.2018.00005.

D'Ancona, M. (2017). Post truth: the new war on truth and how to fight back. London: Ebury Press.

Fazey, I., Schäpke, N., Caniglia, G., Patterson, J., Hultman, J., Van Mierlo, B., et al. (2018). Ten essentials for action-oriented and second order energy transitions, transformations and climate change research. Energy Res. Social Sci. 40, 54-70. doi:10.1016/j.erss.2017.11.026.

Fraune, C., and Knodt, M. (2018). Sustainable energy transformations in an age of populism, posttruth politics, and local resistance. Energy Res.Social Sci. 43, 1-7 doi:10.1016/j.erss.2018.05.029

Galafassi, D., Kagan, S., Milkoreit, M., Heras, M., Bilodeau, C., Bourke, S. J., et al. (2018). 'Raising the temperature': the arts on a warming planet. Curr. Opin. Environ. Sustain. 31, 71-79. doi:10.1016/j.cosust.2017.12.010.

Hoffmann, C. (2018). Beyond the resource curse and pipeline conspiracies: energy as a social relation in the Middle East. Energy Res. Social Sc. 41, 39-47. doi:10. 1016/j.erss.2018.04.025.

P. Hoggett (Editor). (2019). Climate psychology: on indifference to disaster. Cham, Switzerland: Springer.

Hornborg, A. (2011). Global ecology and unequal exchange: fetishism in a zero-sum world. London: Routledge

Huber, M. T. (2009). Energizing historical materialism: fossil fuels, space and the capitalist mode of production. Geoforum 40 (1), 105-115. doi:10.1016/j. geoforum.2008.08.004.

Huber, M. T., and McCarthy, J. (2017). Beyond the subterranean energy regime? Fuel, land use and the production of space. Trans. Inst. Br. Geogr. 42 (4), 655-668. doi:10.1111/tran.12182.

Islar, M., and Busch, H. (2016). "We are not in this to save the polar bears!" - the link between community renewable energy development and ecological citizenship. Innovat. Eur. J. Soc. Sci. Res. 29(3), 303-319. doi:10.1080/ 13511610.2016.1188684.

Jenkins, K. E. H., Stephens, J. C., Reames, T. G., and Hernández, D. (2020). Towards impactful energy justice research: transforming the power of academic engagement. Energy Res. Social Sc. 67, 101510. doi:10.1016/j.erss.2020.101510.

Jenkins, K., Sovacool, B. K., and McCauley, D. (2018). Humanizing sociotechnical transitions through energy justice: an ethical framework for global transformative change. Energy Pol. 117, 66-74. doi:10.1016/j.enpol.2018.02.036.

JPI Urban Europe/SET Plan Action 3.2 (2020). White paper on PED reference framework for positive energy districts and neighbourhoods. Available at: https://jpi-urbaneurope.eu/ped/

Kallis, G. (2019). Limits: why malthus was wrong and why environmentalists should care. Redwood City, CA: Stanford University Press.

Kishimoto, S., Steinfort, L., and Petitjean, O. (2020). The future is public: towards democratic ownership of public services. Amsterdam: Transnational Institute (TNI). Available at: www.tni.org/futureispublic (Accessed October 19, 2020).

Kunze, C., and Becker, S. (2015). Collective ownership in renewable energy and opportunities for sustainable degrowth. Sustain. Sci. 10 (3), 425-437. doi:10. 1007/s11625-015-0301-0. 
Lieu, J., Sorman, A. H., Johnson, O. W., Virla, L. D., and Resurrección, B. P. (2020). Three sides to every story: gender perspectives in energy transition pathways in Canada, Kenya and Spain. Energy Res. Social Sci. 68, 101550. doi:10.1016/j.erss. 2020.101550 .

Mabee, W. (2020). Biden, Keystone XL and a green new deal could shake up Canada's energy industry," The conversation, 27 May, 2020, 8.18 PM, BST, business + economy, https://theconversation.com/biden-keystone-xl-and-agreen-new-deal-could-shake-up-canadas-energy-industry-139362

MacArthur, J., and Matthewman, S. (2018). Populist resistance and alternative transitions: indigenous ownership of energy infrastructure in Aotearoa New Zealand. Energy Res. Social Sci. 43, 16-24. doi:10.1016/j.erss.2018.05.009.

Martinez-Alier, J.. (2009). Social metabolism, ecological distribution conflicts, and languages of valuation. Appl. Econ. Lett. 20 (1), 58-87. doi:10.1080/ 10455750902727378.

McCarthy, J. (2015). A socioecological fix to capitalist crisis and climate change? The possibilities and limits of renewable energy. Environ. Plann. 47 (12), 2485-2502. doi:10.1177/0308518x15602491.

Miller, C. A., Iles, A., and Jones, C. F. (2013). The social dimensions of energy transitions. Sci. Cult. 22 (2), 135-148 doi:10.1080/09505431.2013. 786989.

Nelson, J. (2003). Once more, with feeling: feminist economics and the ontological question. Fem. Econ. 9 (1), 109-118. doi:10.1080/13545700110059261.

Nightingale, A. J., Eriksen, S., Taylor, M., Forsyth, T., Pelling, M., Newsham, A., et al. (2020). Beyond Technical Fixes: climate solutions and the great derangement. Clim. Dev. 12 (4), 343-352. doi:10.1080/17565529.2019. 1624495.

Ruiz Cayuela, S., and Turhan, E. (2019). Wasting democracy, fueling dissent: refuse-derived fuels in can Sant Joan (Catalonia). Front. Energy Res. 6, 142. doi:10.3389/fenrg.2018.00142.

Ryan, S. E. (2014). Rethinking gender and identity in energy studies. Energy Res. Social Sci. 1, 96-105. doi:10.1016/j.erss.2014.02.008.

Scheidel, A., Del Bene, D., Liu, J., Navas, G., Mingorría, S., Demaria, F., et al. (2020). Environmental conflicts and defenders: a global overview. Global Environ. Change. 63, 102104. doi:10.1016/j.gloenvcha.2020.102104.

Scheidel, A., and Sorman, A. H. (2012). Energy transitions and the global land rush: ultimate drivers and persistent consequences. Global Environ. Change. 22 (3), 588-595. doi:10.1016/j.gloenvcha.2011.12.005.

Scoones, I. (2016). The politics of sustainability and development. Annu. Rev. Environ. Resour. 41, 293-319. doi:10.1146/annurev-environ-110615090039.

Shove, E., and Walker, G. (2014). What is energy for? Social practice and energy demand. Theor. Cult. Soc. 31 (5), 41-58. doi:10.1177/0263276414536746.

Shrivastava, P., Stafford Smith, M., O’Brien, K., and Zsolnai, L. (2020). Transforming sustainability science to generate positive social and environmental change globally. One Earth. 2 (4), 329-340. doi:10.1016/j. oneear.2020.04.010.

Sovacool, B. K., Axsen, J., and Sorrell, S. (2018). Promoting novelty, rigor, and style in energy social science: towards codes of practice for appropriate methods and research design. Energy Res. Social Sci. 45, 12-42. doi:10.1016/j.erss.2018.07.007.

Sovacool, B. K. (2014). Diversity: energy studies need social science. Nature 511(7511), 529. doi:10.1038/511529a.

Sovacool, B. K., and Hess, D. J. (2017). Ordering theories: typologies and conceptual frameworks for sociotechnical change. Soc. Stud. Sci. 47 (5), 703-750. doi:10.1177/0306312717709363.
Sovacool, B. K. (2016). How long will it take? Conceptualizing the tempora dynamics of energy transitions. Energy Res. Social Sci. 13, 202-215. doi:10.1016/ j.erss.2015.12.020.

Stanley, J. (2018). How fascism works: the politics of us and them. London: Random House.

Stephens, J. C. (2019). Energy democracy: redistributing power to the people through renewable transformation. Environment 61 (2), 4-13. doi:10.1080/ 00139157.2019.1564212.

Stirling, A.. (2019). How deep is incumbency? A 'configuring fields' approach to redistributing and reorienting power in socio-material change. Energy Res. Social Sci. 58, 101239. doi:10.1016/j.erss.2019.101239.

Sweeney, S. (2012). "Resist, reclaim, restructure: unions and the struggle for energy democracy," in Trade unions for energy democracy, discussion document prepared for the energy emergency: developing trade union strategies for a global transition trade union roundtable, October 10-12, 2012, New York, NY, www.unionsforenergydemocracy.org

Szulecki, K., and Overland, I. (2020). Energy democracy as a process, an outcome and a goal: a conceptual review. Energy Res. Social Sci. 69, 101768.

I. Szeman and D. Boyer (Editors) (2017). Energy humanities: an anthology. Baltimore, MD: JHU Press.

Szulecki, K. (2018). Conceptualizing energy democracy. Environ. Polit. 27 (1), 21-41. doi:10.1080/09644016.2017.1387294.

Tainter, J. A. (2011). Energy, complexity, and sustainability: a historical perspective. Environ. Innov. Societ. Trans. 1 (1), 89-95. doi:10.1016/j.eist.2010.12.001.

Taylor, M. (2020). Half of UK universities have committed to divest from fossil fuel, The Guardian, 13 Jan, 202007.00 GMT. Avilable at: https:// www.theguardian.com/environment/2020/jan/13/half-of-uk-universitieshave-committed-to-divest-from-fossil-fuel

UNEP (2019). Emissions gap report 2019. Nairobi: United Nations Environment Programme. Available online: https:/www.unenvironment.org/resources/ emissions-gap-report-2019

Van Veelen, B., Pinker, A., Tingey, M., Taylor Aiken, G., and Eadson, W. (2019). What can energy research bring to social science? Reflections on 5 years of Energy Research \& Social Science and beyond. Energy Res. Social Sci. 57, 101240. doi:10.1016/j.erss.2019.101240.

Van Veelen, B., and Van Der Horst, D. (2018). What is energy democracy? Connecting social science energy research and political theory. Energy Res. Social Sci. 46, 19-28. doi:10.1016/j.erss.2018.06.010.

Winther, T., Ulsrud, K., Matinga, M., Govindan, M., Gill, B., Saini, A., et al. (2020). In the light of what we cannot see: exploring the interconnections between gender and electricity access. Energy Res. Social Sci. 60, 101334. doi:10.1016/j. erss.2019.101334.

Conflict of Interest: The authors declare that the research was conducted in the absence of any commercial or financial relationships that could be construed as a potential conflict of interest.

Copyright (C) 2020 Sorman, Turhan and Rosas-Casals. This is an open-access article distributed under the terms of the Creative Commons Attribution License (CC BY). The use, distribution or reproduction in other forums is permitted, provided the original author(s) and the copyright owner(s) are credited and that the original publication in this journal is cited, in accordance with accepted academic practice. No use, distribution or reproduction is permitted which does not comply with these terms. 